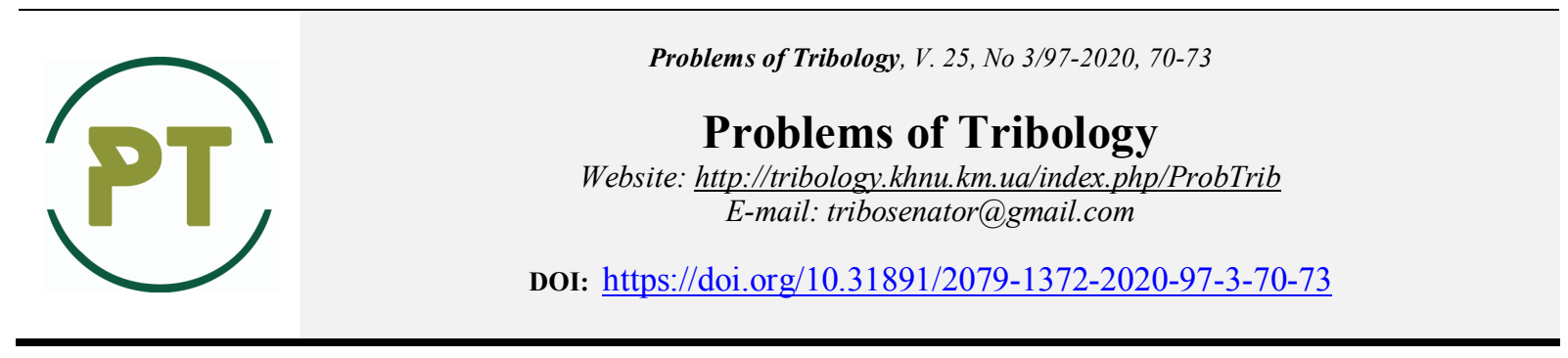

\title{
Management of morphology and structure besieged coatings
}

\author{
V.I. Savulyak, V.Y. Shenfeld ${ }^{*}$, O.P. Shylina, I.V. Vishtak \\ Vinnytsia National Technical University, Vinnytsia, Ukraine \\ *E-mail:leravntu@gmail.com
}

\begin{abstract}
The article investigates structure formation during surfacing of high-carbon coatings. The presence of a functional relationship between the lifetime of the weld pool and the formed structures of the deposited metal has been established. To change the time of existence of the weld pool, it is proposed to use a change in the deposition rate, surfacing modes and other factors. For various modes of existence of the weld pool, the presence of structures where the amount of retained austenite varies within wide limits was revealed. The ability to provide the necessary physical, mechanical and tribological properties has been obtained.
\end{abstract}

Key words: hardfacing coating, control of structure, austenite, martensite, molten's bath.

\section{Introduction}

The wear resistance of materials depends on the conditions of friction and wear, the combination of materials in a friction pair and their structural state. In the works of K. Dies [1], A. G. Kostornov [2], I.V. Kragelsky [3], V.I. Savulyak [4] and other researchers show the possibility of controlling the processes of friction and wear by changing the composition, morphology, structure of friction surfaces and the degree of their metastability. Formation of such properties of friction surfaces already at the stage of applying functional coatings is an urgent task. Therefore, considerable attention of modern tribomaterials knowledge is paid to the creation of wear-resistant surface layers formed by surfacing by various methods.

In the works [5-8], the possibility of using the metastable state of retained austenite for positive structural transformations into martensite and similar structures during friction and wear of surfaces, as well as for absorbing excess energy entering the alloy for relaxation of internal stresses.

Alloys with high initial hardness are traditionally considered to be more wear resistant. An exception to this rule are alloys, in the structure of which, upon cooling, a significant amount of metastable austenite remains, which did not have time to decompose. In the process of wear of such steels with a metastable austenitic structure under the influence of energy from the friction process that enters the surface, deformation martensite can form $[7,8]$.

A significant effect on the strengthening of austenite, its stability with respect to dynamic deformation martensitic transformations and, accordingly, the properties of alloys with unstable austenite are carried out by the previous cold and hot plastic deformations. Depending on the mode of their implementation, they can stabilize or destabilize austenite and ambiguously affect the properties [9]. To reduce the amount of retained austenite and its stabilization, the following technological methods are used: lowering the heating temperature for quenching; cold treatment; aging; deformation to increase the density of stacking faults, etc [10].

The effect of austenite on wear resistance is clearly manifested in alloys, the structure of which, after appropriate heat treatment, has the maximum possible amount of retained austenite without excess carbides.

With an increase in the quenching temperature, the hardness of hypereutectoid alloys decreases due to an increase in the amount of retained austenite in the structure. At the same time, wear resistance increases. The maximum wear resistance is achieved when quenching from $1130^{\circ} \mathrm{C}$ of an alloy with a carbon content of $2.0 \%$, when the maximum possible amount of retained austenite is present in the structure.

The study of the effect of the structure on the wear resistance of steels under conditions of abrasive friction showed that ferrite has the minimum wear resistance, then pearlite and the decomposition products of martensite - sorbitol, trostite, bainite. Their practical use to increase wear resistance, in conditions of abrasive wear, is not recommended - their hardness is low. The phase that can act as a matrix of a wear-resistant alloy is a 
residual metastable austenite that undergoes $\gamma \rightarrow \alpha$ transformation with a deformation martensite interlayer with a microhardness $\mathrm{H}_{50}=8-9 \mathrm{GPa}$ [7]. To ensure high wear resistance, the alloy must contain $50-80 \%$ of the consolidation phase located in the austenitic - martensitic matrix with the ratio $\mathrm{M} / \mathrm{A}=80 / 20 \ldots 60 / 40$.

So, among the available structures of iron-carbon alloys, steels with a high austenite content show high wear resistance under abrasive friction, despite its low initial hardness, much lower than the hardness of both martensite and cementite [7].

A feature of the crystallization of the weld pool during welding or deposition is the spontaneous growth of columnar crystallites from its edges towards the center. Such structure of metal is not optimal, therefore, measures are taken to change it. One of such methods for improving the structure of the deposited metal is the organization of special thermal conditions during its hardening.

In this work, attention is paid to the processes of controlling the crystallization of the weld pool and promoting the formation of metal metastability. The obtained metastability margin can become the driving thermodynamic factor of phase transformations in the solid state and the production of wear-resistant austenitemartinsite structures. The control factor is proposed to use the lifetime of the weld pool.

\section{Purpose}

The purpose of the work is to study the processes of controlling the formation of favorable structures of high-carbon coatings for operation under abrasive friction conditions, obtained by surfacing steel materials using carbon fiber materials, by changing the cooling rate of the system and the lifetime of the weld pool.

\section{Research objects and methods.}

The UT 2 fabric was fixed on the prepared surface with the help of a special glue. The surfacing of the coating was carried out on a UD-209M installation in a $\mathrm{CO}_{2}$ environment on specimens of low-carbon steel St.3 with an Np-30KhGSA wire of 1,2 mm in diameter [11]. The deposition rate varied from 26 to $11 \mathrm{~m} / \mathrm{h}$, which made it possible to change the time of existence of the weld pool in the liquid state from 2 to 5 seconds. The structure was investigated according to standard techniques using scanning electron microscopy.

\section{The discussion of the results.}

During surfacing, as a result of non-equilibrium processes of input of the heat flux from the welding arc, a weld pool is formed, from which heat spreads into the substrate material and the environment due to convection and radiation. As a result, surface structures of various morphologies are formed. The surface structure of specimens with deposited coatings has the following characteristic zones: deposited layer, transition zone (fusion zone) and substrate metal.

As a result of the melting and dissolution of the tissue, in a very limited time interval, the formation of groups of melt components occurs, followed by crystallization. During the primary crystallization of such a melt, austenite is formed, which disintegrate during cooling.

Analysis of the surface of the microstructure (Fig. 1) showed that under the conditions of existence of the weld pool in the liquid state for 5 seconds, $\sim 80 \%$ of martensite, $\sim 20 \%$ of austenite and a small amount of inclusions were formed uniformly in the surface layer.

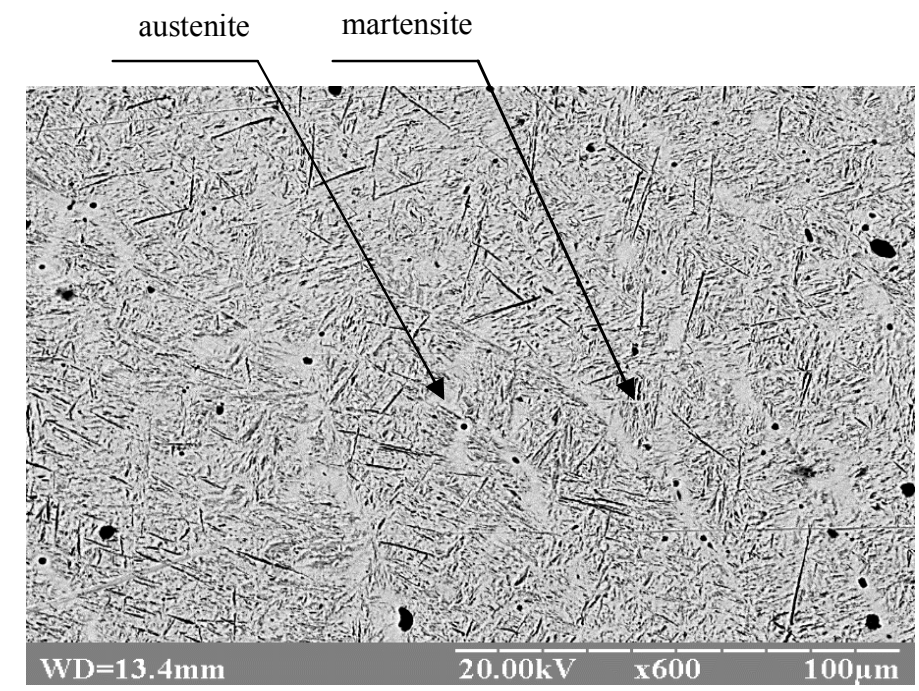

Fig. 1 - Microstructure of deposited high-carbon coating at $t_{p}=5$ seconds 
In the transition zone of the deposited specimen (Fig. 2), the formation of packet martensite ( $60 \%)$, areas of austenite $(\sim 25 \%)$ is observed, as well as a small amount of residues from the process of dissolution of carbon tissuses and inclusion of pearlite.

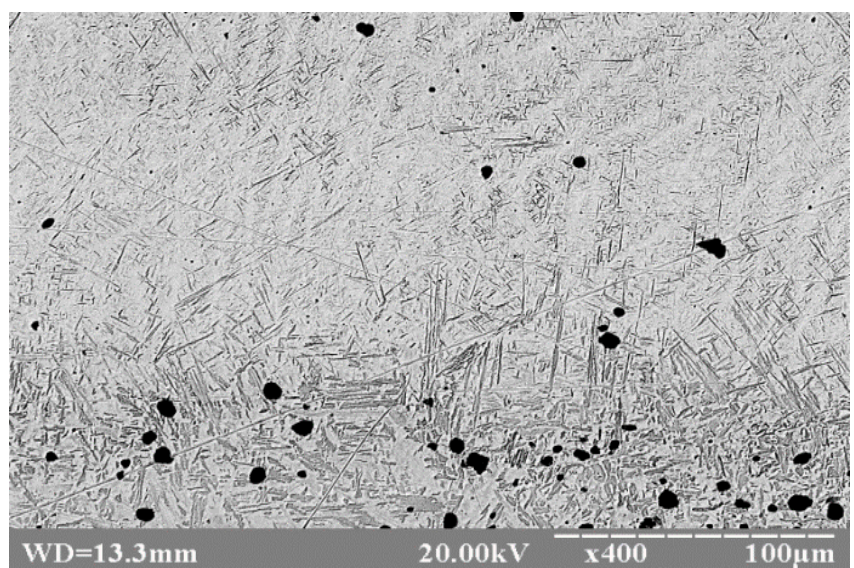

Fig. 2 - Microstructure of the transition zone of the deposited high-carbon coating at $t_{p}=5$ seconds

Under the conditions of the existence of the weld pool for 3 seconds (Fig. 3), martensite and austenite precipitate on the surface of the microstructure. Comparison of the structures shows certain differences, which are as follows: martensite changed its structure from packet to chaotic, and the area of austenite sections increased.
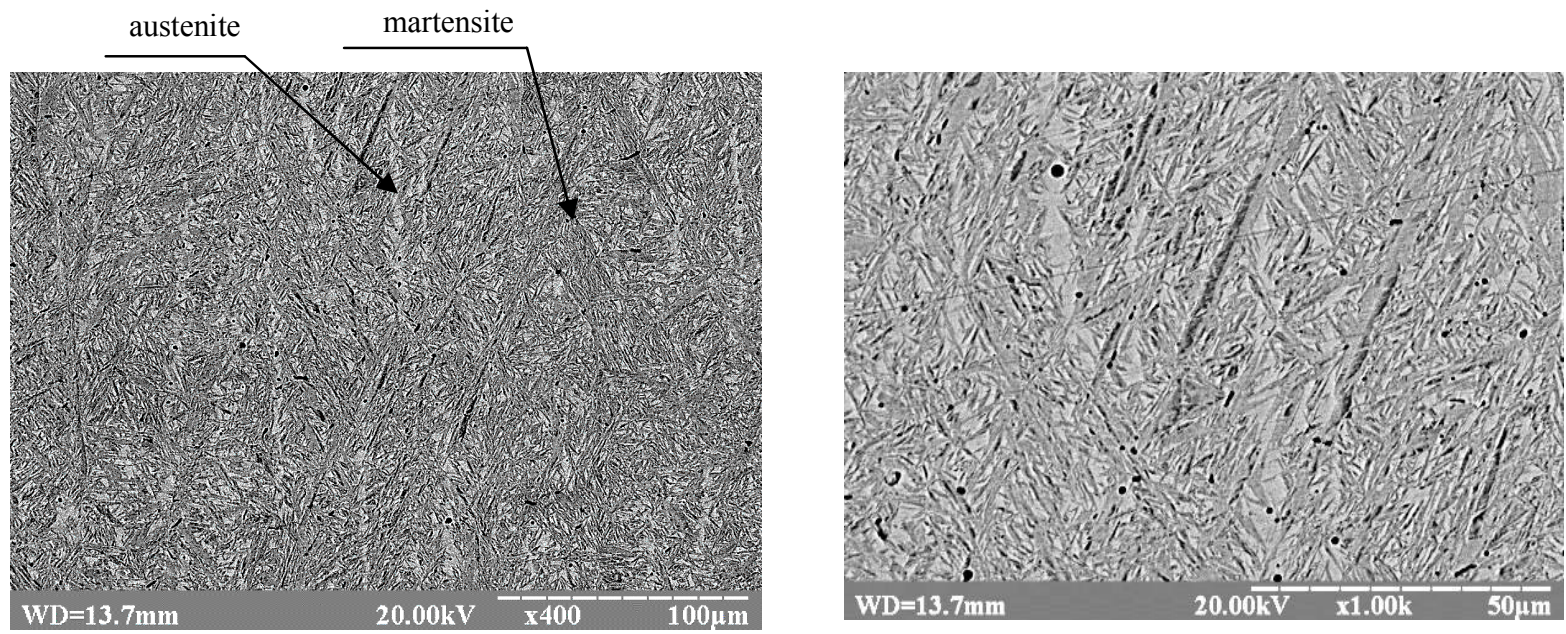

Fig. 3 - Microstructures of the deposited high-carbon coating at $t_{p}=\mathbf{3}$ seconds

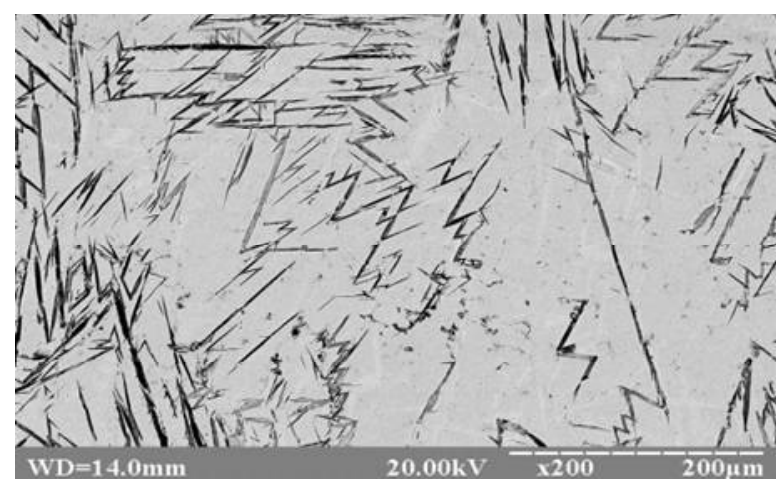

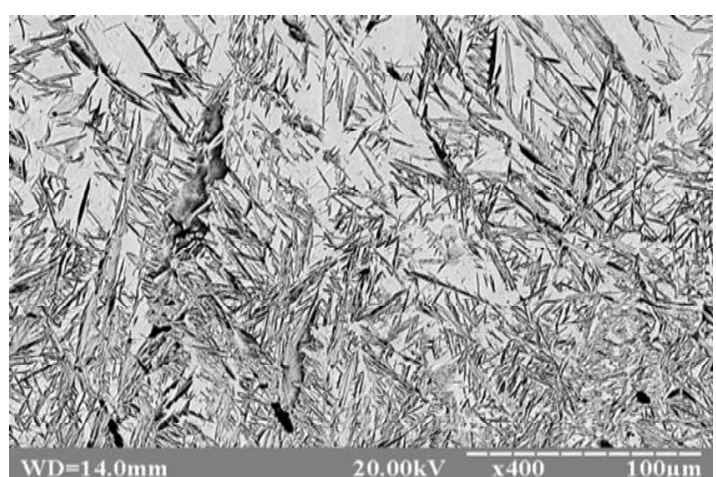

b

Fig. 4 - Microstructure of the deposited high-carbon coating at $t_{p}=2$ seconds:

$$
\begin{gathered}
\text { a - near-surface layer; } \\
\mathbf{b} \text { - the bottom layer }
\end{gathered}
$$


Reducing the life of the weld pool in the liquid state to two seconds affects the change in the formed coating structures (Fig. 4).

Under such conditions, the amount of heat that enters the base metal does not significantly increase its temperature. Therefore, the temperature difference between the weld pool and the base metal is large and the rate of heat removal from it is greater than with a lifetime of 5 and 3 seconds. As a result, the deposited coating is divided into zones with different structures. At Fig. 4a, shows the microstructure of the near-surface part of the deposited layer, where multidirectional packets and individual grains of martensite are observed against the background of austenite. The amount of martensite is not uniform and amounts to $\sim 30 \ldots 35 \%$, and the rest is austenite.

At Fig. 4b, in the lower part of the deposited layer, the percentage of martensite in the fusion zone increases. The morphology of martensite becomes more complicated. The hardness of martensite in the deposited layers is $\mathrm{H} \mu 960 \mathrm{MPa}$.

\section{Conclusion}

1. By changing the lifetime of the weld pool in the process of surfacing a high-carbon coating and the dynamics of thermal processes, it is possible to control the metastability of the formed surface layer, the fraction of retained austenite and its decomposition with the formation of martensite.

2. The lifetime of the weld pool functionally depends on the deposition rate, welding current, wire feed speed and heat dissipation conditions..

3. The obtained ability to provide the necessary physical, mechanical and tribological properties due to phase transformations in the solid state.

\section{References}

1. K. Dies., Archiv fur das Eisenhuttenwessen 16, 399 (1973) [English]

2. Kostornov A. G. Sovremennye predstavleniya o mekhanizme treniya i iznosa tribotekhnicheskih sistem i celenapravlenyj sintez kompozicionnyh antifrikcionnyh materialov dlya zadannyh uslovij ekspluatacii / A. G. Kostornov // 4-ya Ukrainskaya konferenciya po kosmicheskim issledovaniyam. Institut kosmicheskih issledovanij NANU-NKAU. 2004. S.17 [Ukrainian]

3. Kragel'skij I. V. Trenie i iznos / I. V. Kragel'skij. - M.: Mashinostroenie, 1968. - $480 \mathrm{~s}$ [Ukrainian]

4. Savulyak V. I. Naplavlennya visokovuglecevih znosostijkih pokrittiv / V. I. Savulyak, V. Y. Shenfel'd. - Vinnicya: VNTU, 2016. - 124 s [Ukrainian]

5. Popov V.S., Brykov N.N., Dmitrichenko N.S. Iznosostojkost' press-form ogneupornogo proizvodstva. - M.: Metallurgiya, 1971. - 157 s [Ukrainian]

6. CHejlyah A.P. Ekonomnolegirovannye metastabil'nye splavy i uprochnyayushchie tekhnologii. Har'kov: NNC HFTI, 2003. - 212 s [Ukrainian]

7. Popov S. M. Tribotekhnichni ta materialoznavchi aspekti rujnuvannya stalej i splaviv pri znoshuvanni / S. M. Popov, D. A. Antonyuk, V. V. Netrebko - Zaporizhzhya: ZNU, VAT «Motor Sich», 2010, - 368 s.

8. Sorokin V. M. Osnovy tribotekhniki i uprochneniya poverhnostej detalej mashin / V. M. Sorokin, A. S. Kurnikov - N.: Novgorod: VGAVT, 2006 - 296s [Ukrainian]

9. Malinov L. S. Resursosberezhenie za schet primeneniya ekonomnolegirovannyh splavov i uprochnyayushchih tekhnologij, obespechivayushchih poluchenie mnogofaznyh metastabil'nyh struktur i upravlenie strukturnymi i fazovymi prevrashcheniyami / L. S. Malinov, V. L. Malinov // Novi materiali ta tekhnologiï v metalurgiï ta mashinobuduvanni - 2011. - № 1. - Zaporozh'e. - S. 93-105 [Ukrainian]

10. Tenenbaum M. M. Iznosostojkost' konstrukcionnyh materialov i detalej mashin pri abrazivnom iznashivanii. - M.: Mashinostroenie, 1966. - 332 s [Ukrainian]

11. Savulyak V. I. Naplavlennya visokovuglecevih pokrittiv z vikoristannyam vuglecevih volokon / V. I. Savulyak, S.A. Zabolotnij, V. Y. Shenfel'd // Problemi tribologiï. - 2010. - №1. - S.66-70 [Ukrainian]

Савуляк В.І., Шенфельд В.Й., Шиліна О.П., Віштак І.В. Керування морфологією та структурою наплавлених покриттів.

В статті досліджено структуроутворення під час наплавлення високовуглецевих покриттів. Встановлено наявність функціональної залежності між часом існування зварювальної ванни та утворених структур наплавленого металу. Для зміни часу існування зварювальної ванни запропоновано використовувати зміну швидкості наплавлення, режими наплавлення та інші фактори. Для різних режимів існування зварювальної ванни виявлено наявність структур, де кількість залишкового аустеніту коливається в широких межах. Отримана можливість забезпечувати необхідні фізико-механічні та трибологічні властивості.

Ключові слова: наплавлене покриття, керування структурою, аустеніт, мартенсит, розплавлена ванна. 